\title{
Türk Antrenörlerin Spor Psikolojisine İlişkin Bilgi Düzeyleri ve Tutumları
}

\author{
Knowledge Levels and Attitudes of Turkish Coaches About Sport Psychology
}

\author{
${ }^{1}$ Deniz DURDUBAŞ \\ ${ }^{2}$ Selen KELECEK \\ ${ }^{1}$ Ziya KORUÇ
}

${ }^{1}$ Hacettepe Üniversitesi, Spor Bilimleri Fakültesi, Egzersiz ve Spor Bilimleri Bölümü, ANKARA

${ }^{2}$ Başkent Üniversitesi Sağlık Bilimleri Fakültesi, Spor Bilimleri Bölümü, ANKARA

\section{Yazışma Adresi \\ Corresponding Address:}

Arş. Gör. Deniz Durdubaş

ORCID: 0000-0002-4186-293X

Hacettepe Üniversitesi, Spor Bilimleri Fakültesi, Egzersiz ve Spor Bilimleri Bölümü, Egzersiz ve Spor Psikolojisi ABD, 06800 Beytepe / ANKARA

\section{E-posta:}

deniz.durdubas@hacettepe.edu.tr

\section{öz}

Bu çalışmanın amacı ülkemizdeki antrenörlerin spor psikolojisi bilgi düzeylerine ilişkin algılarının belirlenmesi ve antrenörlerin bu algılarının spor psikolojisi danışmanlığına yönelik tutumları ile ilişkisinin incelenmesidir. Çalışmaya farklı spor branşlarından toplam 313 antrenör katılmıştır. Antrenörlerin spor psikolojisine ilişkin bilgi düzeyleri araştırmacılar tarafından ilgili literatürden hareketle geliştirilen anket ile ölçülmüştür. Antrenörlerin spor psikolojisi hizmetlerine yönelik tutumlarının ölçümü için ise Antrenörlerin Spor Psikolojisi Tutumları Ölçeği Kısaltılmış Versiyonu (Shortened Version of the Sport Psychology Attitudes Revised Coaches - 2, SPARC-2) Türkçe'ye uyarlanarak kullanılmıştır. Bulgular tüm antrenörlerin spor psikolojisi bilgilerinin sınırlı olduğunu ve daha üst antrenörlük kademesine sahip antrenörlerin spor psikolojisi hizmetlerine daha açık olduklarını ortaya koymuştur. Bu sonuçlar ülkemizde spor psikolojisi hizmetlerinin arttırılması adına antrenörlerin spor psikolojisi eğitimlerinin önemini ortaya koymaktadır.

Anahtar Kelimeler: Spor psikolojisi tutumları, Antrenörler, Spor psikolojisi danışmanlığı

\section{ABSTRACT}

Purposes of this study were to exploring the Turkish coaches' sport psychology knowledge levels and examining the relationship between knowledge levels and attitudes toward sport psychology consulting. Three hundred and thirteen coaches from various sports took part in the study. Knowledge levels of participants were determined by a survey developed by the researchers from relevant literature. In order to measure the attitudes of the coaches towards sport psychology services, the Shortened Version of Sport Psychology Attitudes Revised Coaches-2 Scale was adapted to the Turkish language and applied to coaches. Findings revealed that the coaches have average knowledge about sport psychology, and that coaches with a higher level of certification were more open to sports psychology services. These results reveal the importance of sports psychology education of coaches to increase sports psychology services in our country.

Key Words: Sport psychology attitudes, Coaches, Sport psychology consultantcy 


\section{GíRIŞ}

Modern sporun artan biçimde profesyonelleşmesiyle, takımlar ve sporcular multidisipliner yaklaşımları benimsemekte ve buna bağlı olarak performanslarını arttırmak amacıyla, çok çeşitli spor uzmanlarından (örneğin, fizyoterapist, kondisyoner) destek almaktadırlar (Reid ve diğ., 2004). Günümüzde sporcuların çoğu uzman bir destek ekibi tarafından çevrelenmiştir ve bu destek ekibinin sayısı yarışma düzeyi ile paralel olarak artmaktadır. Genel anlamda çeşitli performans arttırma stratejileri, psikolojik beceri antrenmanları (Arnold ve Sarkar, 2015; Gucciardi ve diğ., 2009), motivasyonel faktörler (Mallett ve Hanrahan, 2004) ve sporcuların optimal psikolojik durumları (Anderson ve diğ., 2014) gibi konulara odaklanan spor psikolojisi danışmanları (SPD), bu destek ekibinin vazgeçilmez bir üyesi haline gelmiştir.

Spor psikolojisinin hızlı gelişimi ve artan farkındalığa rağmen, profesyonel takımlarda tam zamanlı olarak istihdam edilen SPD sayısı halen düşüktür (Reverter-Masía ve diğ., 2008; Zakrajsek ve diğ., 2013). Bu durum kimi araştırmacılara göre spor psikolojisi hizmetlerinin spor ortamlarında kullanılmasına ilişkin süregelen tereddütlerden kaynaklanmaktadır (Anderson ve diğ., 2004; Gee, 2010; Martin ve diğ., 2002). Bu tereddütlerin nedenlerinin ve çeşitli spor katılımcılarının hizmet taleplerinin daha iyi anlaşılması için spor psikolojisi hizmetlerine ilişkin tutumlar, inançlar, algılar ve engeller uzunca bir süredir araştırılmaktadır (Connole ve diğ., 2014; Martin, 2005; Pain ve Harwood, 2004; Wilson ve diğ., 2009; Wrisberg ve diğ., 2012). Bu araştırma alanlarının merkezinde beklendiği üzere sporcular ve onların spor psikolojisine yönelik tutumları yer almaktadır (Martin, Zakrajsek, \& Wrisberg, 2012). Bulgular, spor türü, yarışma düzeyi, cinsiyet ve kültürel farklılıklar gibi birçok değişkenin sporcuların spor psikolojisine yönelik tutumlarında önemli rol oynadığını göstermektedir (e.g., Anderson ve diğ., 2004; Martin, 2005; Martin ve diğ., 2001; Martin ve diğ., 2002). Spor psikolojisi alanının genişlemesi adına sporcuların spor psikolojisi ve hizmetlerine ilişkin tutumlarının anlaşılması önemliyken antrenörlerin bu alana yaklaşımı da aynı derecede önemlidir.

Antrenörlerin SPD’lerin işe alımlarında karar verici pozisyonda olmaları ve sporcuların spor psikolojisine ilişkin görüşlerini etkileyebilecek aktörler olmaları sebebiyle tutumları, algıları ve tercihleri spor psikolojisi hizmetleri açısından önemlidir (Dieffenbach ve diğ., 2002; Orlick ve Partington, 1987). Antrenörlerin SPD’lerle çalışma nedenleri ve kararları bu noktada iki ayrı özellik olarak karşımıza çıkmaktadır. Antrenörlerin SPD’lerle çalışma nedenlerine baktığımızda geçmiş çalışmalarla tutarlı olarak SPD'lerin performans problemlerinin ortadan kaldırılmasında ve performansın artırılmasında verdikleri desteği görmekteyiz. Wrisberg ve ark. (2010) tarafından Kolej Ligi'nde çalışan 815 antrenörle yapılan çalışmada, antrenörlerin SPD’lerle çalışma nedenlerindeki birincil önceliğin kişisel sorunlardan çok performans konuları olduğu ve antrenörlerin özellikle zihinsel antrenman hizmetlerinin sağlanabilmesine odaklandıkları tespit edilmiştir. Zihinsel antrenman yoluyla performansın geliştirilmesi, daha önceki çalışmalarla tutarlı olarak SPD'lerin temel rolü olarak algılanmakta ve bu roldeki performansları antrenörlerin SPD’lerle çalışma tercihlerini belirlemektedir (Gould, Tammen, Murphy ve May, 1991; Thelwell, Wood ve Harwood, 2018). Diğer taraftan antrenörlerin SPD’lerle çalışma kararlarında özellikle danışmanların çalışma stilleri ve kişisel özelliklerinin etkili olduğu görülmektedir. Bu bağlamda antrenörlere ilişkin yapılan ilk çalışma Partington ve Orlick (1987) tarafindan 17 Kanadalı Olimpik antrenörle yapılan nitel bir çalı̧̧madır. Araştırmacılar yaptıkları görüşmelerde antrenörlerin Olimpiyat Oyunlarında sporcularıyla çalışan SPD'lere ilişkin algılarına ve tercihlerine odaklanmışlardır. Elde edilen bulgular antrenörlerin açık ve esnek danışmanlarla çalışmak istediğini ve çeşitli çalışma stillerini benimsediklerini ortaya koymuştur. Ayrıca yapılan araştırmalar danışmanların iletişim becerileri, bilgi ve deneyimlerinin antrenörlerin SPD'ler ile çalışma kararını etkileyen önemli özellikler olduğunu göstermektedir (Thelwell, Wood ve Harwood, 2018; Lubker, Visek, Geer ve Watson, 2008). 
$\mathrm{Bu}$ araştırma alanı yöntemsel olarak incelendiğinde antrenörlerin tutumlarının nicel olarak ölçülmesini sağlayan çeşitli ölçeklerin geliştirildiğini görebiliriz (Örneğin; Sport Psychology Attitudes-Revised, SPA-R, Martin ve diğ., 2002; Sport Psychology Attitudes Revised Coaches-2, SPARC-2, Zakrajsek ve Zizzi, 2007). Bu ölçeklerin en sık kullanılanlarından olan ve antrenörlerin spor psikolojisi tutumlarını inceleyen SPARC-2 (Zakrajsek ve Zizzi, 2007), tıpkı sporcuların tutumlarını inceleyen SPA-R ölçeğinde olduğu gibi, dört faktörden oluşmaktadır: Stigma tolerans (danışmanlığa yönelik olumsuz tutum); spor psikolojisi danışmanlığına güven (zihinsel antrenmanın faydasına olan inanç), kişisel açıklık (spor psikolojisi danışmanlığına katılmama isteği) ve kültürel tercih (kültürel olarak benzer geçmişe sahip bir SPD ile çalışma). Spor psikolojisi tutumlarına ilişkin bu kavramsallaştırma ve bağlantılı ölçüm aracı, antrenörlerin çok çeşitli kişisel özelliklerinin (yaş, cinsiyet vb.) tutumlarını nasıl etkilediğinin ortaya konulmasını sağlamıştır.

Antrenörlerin SPD'lerle çalışma kararlarında yalnızca danışmanların rolü ve özellikleri değil aynı zamanda antrenörlerin kişisel özellikleri de önemlidir. Yapılan çalışmalar kadın antrenörlerin danışmanlığa daha açık olduğunu ve hizmet kullanımını daha az damgalama yaptıklarını ortaya koymuştur (Wrisberg ve diğ., 2010; Zakrajsek ve Zizzi, 2007). Ayrıca, daha deneyimli ve eğitimli antrenörlerin daha genç olan antrenörlere göre spor psikolojisi hizmetlerine daha yatkın oldukları, danışmanlığın faydasına güvendiklerini ve spor psikolojisini daha az damgalama yapıldı̆̆ı görülmüştür. Bu noktada antrenörlerin çalıştı̆ı spor branşları da spor psikolojisine yönelik tutumları etkilemektedir. Örneğin daha az erkek egemen ve erkeksiliğin olduğu sporlarda (yüzme ve atletizm gibi) çalışan antrenörlerin, bu özelliklerin yüksek olduğu sporlarda (Amerikan futbolu gibi) çalışan antrenörlere göre spor psikoloğu danışmanlığına daha açık ve güvenli oldukları görülmüştür (Zakrajsek ve ark., 2011; Zakrajsek ve Zizzi, 2007, 2008). Antrenörlere ait bu kişisel özellikler arasında spor psikolojisine ilişkin bilginin önemli bir yeri bulunmaktadır.

Antrenörlerin spor psikolojisi bilgisi, danışmanlığa yaklaşımlarını belirleyen en tutarlı özelliklerden birisidir. Hem geçmiş çalışmalar hem de yakın dönemde yapılan çalışmalar yüksek düzeyde spor psikolojisi bilgisine sahip antrenörlerin danışmanlığa karşı daha açık olduklarını ve daha fazla güvendiklerini ortaya koymuştur (Wrisberg ve diğ., 2010; Zakrajek, Martin ve Zizzi, 2011; Zakrajsek ve Zizzi, 2007). Genel sosyal psikoloji alanındaki bilgi - tutum ilişkisinden hareketle (Krosnick ve Petty, 1995), daha fazla spor psikolojisi bilgisine sahip antrenörlerin spor psikolojisi danışmanlığına karşı daha yüksek olumlu tutum geliştirmeleri beklenen bir bulgu olarak değerlendirilebilir. Ancak spor psikolojisi alanının yeni geliştiği ülkelerde bilginin kaynakları ve kaliteleri halen sorgulanabilir durumdadır. Halihazırda alanın geliştiği ülkelerde yapılan geçmiş çalışmalara (spor psikolojisinin gelişmekte olduğu dönemler) baktığımızda benzer problemlere dikkat çeken çalışmalarla karşılaşabiliriz. Örneğin Sullivan ve Hodge (1991), 46 antrenöre uyguladıkları anketle onların spor psikolojisine ilişkin algılarını incelemiş ve antrenörlerin kendi spor psikolojisi bilgilerini sınırlı olarak algıladıklarını ortaya koymuştur. Bunun nedeni olarak araştırmacılar katılımcıların spor psikolojisine ilişkin bilgileri yalnızca temel kitaplardan almasını ve antrenörlük kurslarında, eğitimlerinde spor psikolojisine ait pratik bilgilerin yer almaması olarak işaret etmişlerdir. Antrenörlük kurslarında ya da üniversitelerin antrenör eğitimi bölümlerinde verilen spor psikolojisinin eğitimi içeriğinin yanında, ülkemizde spor psikolojisine olan artan ilgi nedeniyle bazı kuruluşların ve özel girişimlerin bünyesinde açılan "yetkinliği sorgulanabilir" kurslar aracılığı ile de spor psikolojisi eğitimi sağlanmaktadır. Bunun gibi yapısal sorunların antrenörlerin spor psikolojisi danışmanlığına ilişkin yaklaşımlarını etkileyebileceği göz ardı edilmemelidir.

Bu bağlamda ülkemizde SPD’lerin yetiştirilmesi konusunda üzerine uzlaşılmış bir yapının olmaması önemli bir yapısal sorundur. Genel anlamda ülkemizde SPD’lerin yetiştirilmesi üniversitelerde lisans ve lisansüstü düzeyinde sürdürülmekte ve spor federasyonlarının bazıları tarafından açılan antrenörlük kurslarında verilmektedir. Bunların yanında bazı özel iştirakler tarafından açılan kurslarla spor psikolojisi eğitimi adı altında eğitimler verilmekte ve maalesef 
aslında nitelikli bir eğitim gerektiren bu konu sertifika düzeyine indirilmiş durumdadır. Örneğin Avrupa Spor Psikolojisi Federasyonu (FEPSAC), SPD sertifikasyonu sürecini Avrupa için 2019 yılında başlatmayı öngörmekte ve bu kapsamda adaylardan bir lisansüstü yeterlik belgesi (Minimum 240 AKTS), spor psikolojisinde bir alanda özelleşme, süpervizörlük uygulaması (belgelenmiş 250 saatlik uygulama) ve spor ve egzersiz psikolojisinde kültürel uygulamaların yetkinliği ve etik uygulamalara bağl1lığına ilişkin belgeler talep etmektedir (Schinke ve diğ., 2018). Gelişmiş ülkelerde görebildiğimiz üzerinde uzlaşılmış bu türden bütünlüklü bir eğitimin olmayışı spor psikoloji hizmetlerinin kimin tarafından verilmesi gerektiği sorusunu ülkemizde halen yanıtsız bırakmaktadır (Görgülü, 2018; Bayar, 2011). Bu durum, nitelikli bir SPD eğitiminin önünde bir engel oluşturarak sahada çalışan antrenörlerin spor psikolojisine bakış açısını da etkilemektedir.

Bütün bu sorunlara rağmen spor psikolojisi alanı Türkiye'de giderek gelişmektedir ve antrenörler spor psikolojisini performans açısından oldukça gerekli görmektedirler (Bayar, 2011). Literatür incelemesine göre antrenörlerin spor psikolojisine yönelik tutumları henüz araştırılmamıştır ve konuya ilişkin amprik çalışmaya ihtiyaç vardır. Ülkemizdeki spor kültürü göz önüne alındığında oldukça etkin bir rolde olan antrenörlerin spor psikolojisine ilişkin tutumları ve bu tutumların oluşmasını sağlayan bilgilerinin ne düzeyde olduğunun anlaşılması alan açısından oldukça önemlidir. Bu bakımdan yapılan bu çalışmanın amacı ülkemizdeki antrenörlerin spor psikolojisi bilgi düzeylerine ilişkin algılarının belirlenmesi ve antrenörlerin bu algılarının spor psikolojisi danışmanlığına yönelik tutumları ile ilişkisinin incelenmesidir.

\section{YÖNTEM}

Araştırma Grubu: Çalışmaya farklı takım sporlarında $(n=245)$ ve bireysel sporlarda $(n=68)$ çalışan 313 antrenör (Myaş $=38.24 ; \mathrm{SD}=10.19)$ katılmıştır. Katılımcıların ortalama antrenörlük deneyimi 10.89 ( $\mathrm{SD}=8.48)$ yıldır. Spor branşlarında uygulanan farklı antrenörlük kademeleri bulunması nedeniyle katılımcıların antrenörlük sertifika düzeyleri 5 kategoriye ayrılmıştır ( $1=$ En düşük düzey, $5=$ En üst düzey). Sertifika kategorileri antrenörlerin deneyimlerini ve bulundukları yarışma düzeyini yansıtmaktadır. Antrenörler genellikle kariyerlerine 1. kademe antrenörlük sertifikası alarak başlarlar ve çeşitli ölçütlerle birlikte katıldıkları antrenörlük kurslarıyla daha üst kategorilere yükselirler. Örneğin, 2. kademe sertifikaya sahip olan bir basketbol antrenörü 3. kademeye geçebilmek için bulunduğu düzeyde en az 2 sene bir antrenörün yanında ya da basketbol okulunda çalıştığını belgelemeli, iki yıl içinde en az iki antrenör gelişim seminerine katılmalı ve 3. kademe için açılan antrenörlük kursunu başarıyla bitirmelidir (TBF, 2014). Bu çalışmada katılımcı antrenörlerin \%20'si 1. kademe, \%65'i 2. ve 3. kademe, \%15'i ise 4. ve 5. kademeye sahiptir.

\section{Veri Toplama Araçları:}

Antrenörlerin Spor Psikolojisi Bilgilerine İlişkin Algıları: Antrenörlerin spor psikolojisi bilgilerine ilişkin algılarını ölçmek amacıyla araştırmacılar tarafından bir anket formu hazırlanmıştır. Anket iki ana bölümden oluşmaktadır: (a) betimleyici bilgiler ve (b) spor psikolojisine ilişkin bilgiler. Genel bilgiler bölümünde antrenörlerin bilgi kaynakları, SPD'lerle çalışma tercihleri ve spor psikolojisinin önemine ilişkin kavrayışlarına yönelik sorular bulunmaktadır. İkinci bölümde ise katılımcılara beşli Likert ( $1=$ hiç bilmiyorum, $3=$ kısmen biliyorum, $5=$ çok iyi biliyorum) formunda hazırlanan bir anketle pratik ( 7 madde) ve kuramsal ( 8 madde) spor psikolojisi kavramlarına ilişkin sorular sorulmuştur. Pratik bölüm hedef belirleme, zihinsel dayanıklılık, imgeleme, stresle baş etme stratejileri, kendi kendine konuşma, gevşeme antrenmanı ve konsantrasyon gibi spor psikolojisi tekniklerine ilişkin soruları içerirken, kuramsal bölüm ise yaşam becerilerinin öğretimi, motivasyon, sporcu kişiliği, iletişim, sakatllktan geri dönüş, özfarkındalık, pekiştirme ve zihinsel dayanıklılık kavramlarını içermektedir. Ankette pratik bölüm soruları "lütfen aşağıda sıralanan spor psikolojisi tekniklerine ilişkin bilginizi puanlayınız" ifadesiyle katılımcılara sunulmuştur. Teorik bölüm 
ise "sporculardaki farklı kişilik özellikleri ve bunların performansa etkisi hakkındaki bilginizi puanlayınız" şeklinde sorulardan oluşmaktadır. Anketteki tüm sorular literatürde kullanılan diğer anketlerden hareketle ankete dahil edilmiştir (örneğin, Pain ve Harwood, 2004; Sullivan ve Hodge, 1991). Anketin puanlaması her bir bölüm ve toplam puan üzerinden ortalama skorlar elde edilerek hesaplanmıştır. Anket güvenirliği ankette yer alan bölümlerin ve anketin tümünün iç tutarlılık katsayılarının hesaplanması yoluyla test edilmiştir. Cronbach Alpha güvenirlik katsayıları pratik bölüm için .92; kuramsal bölüm için .85 ve anketin bütünü için .91 olarak bulunmuştur.

Spor Psikolojisine Yönelik Tutumlar: Antrenörlerin spor psikolojisine yönelik tutumları, Antrenörlerin Spor Psikolojisi Tutumları Ölçeği Kısaltılmış Versiyonu (Shortened Version of the Sport Psychology Attitudes Revised Coaches - 2, SPARC-2, Zakrajsek ve Zizzi, 2007, 2008). Orijinal SPARC-2 ölçeği, antrenörlerin tutumlarını ölçmek amacıyla sporcular için hazırlanan Spor Psikolojisi Tutumları-Revize ölçeği (SPA-R; Martin ve diğ., 2002) adapte edilerek oluşturulmuştur. SPARC-2 ölçeğinin orijinal formu, antrenörlerin spor psikolojisine yönelik tutumlarını 4 boyutta inceleyen 26 maddeden oluşmaktadır. Bu boyutlar; Kişisel Açıklık (örnek madde: "Sporcuların duygusal zorlukları zamana bırakılırsa kendiliğinden çözülme eğilimindedir”); Kültürel Tercih (örnek madde: "Sporcularım kendileri ile aynı kültürden gelen bir spor psikolojisi danışmanı ile daha rahat hissederler”); Stigma Tolerans (örnek madde: "Eğer sporcularım bir spor psikolojisi danışmanı ile çalışsaydı, diğer antrenörlerin bunu bilmesini istemezdim") ve Spor Psikolojisi Danışmanlığına Güven: (örnek madde: "Sporcularımı daha iyi anlamamda bana yardım etmesi için bir spor psikolojisi danışmanının yardımını almak isterdim”). SPARC-2'nin kısaltılmış versiyonu ise aynı 4 boyutu içermekte ve 15 sorudan oluşmaktadır. Cevaplar altılı Likert ( $1=$ kesinlikle katılmıyorum, $6=$ kesinlikle katılıyorum). Kısaltılmış versiyonun Türkçe uyarlaması dil uzmanları ve araştırmacılar tarafından gerçekleştirilmiştir. Ölçeğin, geçerlik ve güvenirliği açımlayıcı ve doğrulayıcı faktör analizi ile test edilmiştir. Açımlayıcı faktör analizi sonuçlarına göre KasierMeyer-Olkin örneklem uygunluğu değeri .78 ile önerilen .6’lık değerin üzerinde bulunmuş ve Bartlet küresellik testinin ise anlamlı olduğu görülmüştür $(\chi 2(105)=1247.57 ; p<.05)$. Bu ön koşullar sağlandıktan sonra varimax dönüşümleriyle varyans açıklama oranı $\% 60$ olarak bulunmuştur. Madde faktör yüklerinin ise .53 ile .82 arasında değiştiği bulunmuştur. Doğrulayıcı faktör analizi ise önerilen modelin veri setine iyi bir biçimde uyduğunu göstermiştir, $\chi^{2} / \mathrm{df}=1.445 ; \mathrm{p}=.005 ; \mathrm{CFI}=.957 ; \mathrm{RMSEA}=.039$. Ölçek iç tutarl11ık katsayılarına ilişkin Cronbach alfa değerleri ise .61 ile .80 arasında değişmektedir (stigma tolerans $=.80$; kişisel açıklık=.61; spor psikolojisi danışmanlığına güven $=.75$; kültürel tercih= .75). Futbol antrenörleri örnekleminde geliştirilen orijinal formda ise bu değerler şu şekildedir: stigma tolerans= .81 ; kişisel açıklık $=.69$; spor psikolojisine güven $=.75$; kültürel tercih $=.81$.

İşlem Yolu: Hacettepe Üniversitesi etik kurulundan (Etik Komisyon, No: 82416169) araştırma için alınan onay sonrasında ölçek ve anketten oluşan bir form Google Forms program kullanılarak internet ortamında hazırlanmıştır. Daha sonra yazarlar, spor kuruluşları ve federasyonlar ile iletişime geçmiş ve formun bu kuruluşların bünyelerinde bulunan aktif antrenörlerine gönderilmesi için izin talep etmiştir. İzinlerin alınmasından sonra federasyonların bünyelerindeki antrenörlere web ortamında hazırlanan form mail yoluyla gönderilmiştir. Bunun yanında formun basılı versiyonları da antrenörlük kurslarında ve ulusal turnuvalarda antrenörlere dağıtılmıştır. Formun her iki versiyonu da etik kurulun öngördüğü gönüllü katılım onayını içermektedir.

Verilerin Analizi: Veri analizi tanımlayıcı istatistikleri, bilgi anketi skorlarını ve ölçekten alınan puanları içermektedir. Analizlerden elde edilen sonuçların yorumlanmasını kolaylaştırabilmek adına antrenörler sertifika kademelerine göre düşük düzey (1. ve 2. kademe), orta düzey (3. kademe) ve yüksek düzey (4. ve 5. kademe) olmak üzere üç gruba ayrılmışlardır. Sertifika düzeyleri bakımından antrenör tutumları arasında anlamlı bir farkın bulunup bulunmadığının test edilmesi için çok değişkenli varyans analizi (MANOVA) öngörülmüş̧ür. Bu bağlamda kullanılan 
tutum ölçeğinin alt boyutları (stigma tolerans, kişisel açıklık, kültürel tercih ve spor psikolojisi danışmanlığına güven) analize bağımlı değişken, antrenör sertifika kademeleri ise gruplandırılarak bağımsız değişkenler olarak analize dahil edilmiştir. Daha sonra MANOVA analizinin temel varsayımlarından olan çoklu normallik (multivariate normality) Kolmogorov-Smirnov testi ile sınanmıştır. Test sonuçları tüm alt gruplar düzeyinde anlamlılık göstermiş $(p<.05)$ ve normallik dağılımı sağlanamamıştır. Normallik dağılımı sağlanamadığından oluşturulan antrenör gruplarının tutum puanları arasında anlamlı bir farkın olup olmadığı çok değişkenli parametrik olmayan çıkarım yöntemi (Bathke, Harrar, \& Madden, 2008) ile test edilmiştir. Bir tür parametrik olmayan MANOVA olan bu yöntemin R programındaki paketi npmv ismiyle (Ellis, Burchett, Harrar, \& Bathke, 2017) CRAN deposunda bulunmaktadır (http://CRAN.Rproject.org/package=npmv). Paketin kullandığı parametrik olmayan çok değişkenli yöntem MANOVA'nın aksine çoklu normallik varsayımının sağlanmasına ihtiyaç duymamaktadır (Ellis, Burchett, Harrar, \& Bathke, 2017). Yöntem temelde permutasyon ve F-testi yaklaşımlarıyla p değerlerini elde etmekte ve çoklu test algoritmalarıyla familywise hata oranını azaltmaktadır. Parametrik olmayan görece etkiler, Wilcoxon-Mann-Whitney rank sum testi aracılığı elde edilen etkilerin genişletilmiş halidir ve veride gözlemlenen eğilimleri yansıtırlar (Brunner, Domhof ve Langer, 2002). Son olarak antrenörlerin bilgilerine ilişkin algılarıyla spor psikolojisi tutumları arasındaki ilişkinin belirlenmesinde korelasyon analizi kullanılmıştır. Tüm analizler SPSS 25.0 ve R istatistik programları (v.3.3.3; R Core Team, 2013) kullanılarak gerçekleştirilmiştir.

\section{BULGULAR}

Katılımcı antrenörlerin \%86'sı spor psikolojisinin performans için oldukça önemli olduğunu belirtmiştir. Katılımcıların hemen hemen tamamı (\%98) spor psikolojine ilişkin bir seminere katılmak istediklerini ve \%93’ü ise takımlarında bir spor psikoloğu ile çalışmak istediklerini ifade etmişlerdir. Ayrıca antrenörlerin spor psikolojine ilişkin bilgiye farklı kaynaklardan ulaştıkları görülmüştür: internet (\%68); kitaplar (\%65); antrenörlük kursları (\%65); üniversitede alınan dersler (\%49) ve diğer kaynaklar (\%17).

Antrenörlerin bilgi düzeyi algılarını ve tutumlarına ilişkin ortalama skorlarına bakıldığında (Tablo 1), antrenörlerin bilgi puanlarının ortalama bir düzeyde olduğu ( $\mathrm{x}: 3.61 \pm .67)$ ve antrenörlerin konsantrasyon teknikleri, imgeleme ve hedef belirleme gibi konularda bilgi algılarının görece yüksek olduğu görülmektedir. Antrenörlerin spor psikolojisine ilişkin genel kavramlara yönelik bilgi algılarına bakıldığında, iletişim becerileri, kişilik özellikleri ve spor becerilerinin yaşama aktarılması gibi konularda kendi bilgilerini çok daha üst düzeyde olarak algıladıkları belirlenmiştir.

Antrenörlerin spor psikolojisine yönelik tutumlarının sertifika düzeylerine göre farklılaşıp farklılaşmadığı parametrik olmayan MANOVA yöntemi ile (Ellis ve ark., 2017) test edilmiştir. Sonuçlara göre gruplar arasında anlamlı bir fark olduğu tespit edilmiştir, ANOVA-type $\mathrm{F}(6,731)=2.914, \mathrm{p}=.005$. Npmv paketi, analize giren bağımlı değişkenleri (stigma tolerans, kişisel açıklık, kültürel tercih ve spor psikolojisi danışmanlığına güven) temel alarak bu farkın hangi değişkenlerden kaynaklandığını hesaplayan algoritmalar kullanmakta, hipotez testleriyle (örneğin stigma tolerans için grupların eşitliği hipotezi) grupların eşitliğini sınamakta ve ilgili değişkenler için parametrik olmayan görece etkileri hesaplamaktadır (Ellis ve ark., 2017). Sonuçlara göre grupların her bir değişsken için grupların eşitliği hipotezi yalnızca kişisel açıklık alt boyutu için reddedilmiştir. Buna göre gruplar arası fark kişisel açılık alt boyutundan kaynaklanmaktadır. Tablo 2'de sunulan görece etkiler incelendiğinde yüksek sertifika düzeyindeki antrenörlerin kişisel açıklık düzeylerinin diğer antrenör kademelerinden ayrıldığı görülmektedir. Tüm alt düzey algoritmalar için Tip I hata oranı a $=.05$ olarak alınmıştır. 
Tablo 1. Sertifika düzeyine göre bilgi ve tutum puanları ortalamaları (Ort $\pm \mathrm{Ss}$ )

\begin{tabular}{|c|c|c|c|}
\hline Sertifika Düzeyleri & $\begin{array}{l}\text { Düşük } \\
n=163\end{array}$ & $\begin{array}{c}\text { Orta } \\
n=101\end{array}$ & $\begin{array}{c}\text { Yüksek } \\
n=41\end{array}$ \\
\hline \multicolumn{4}{|l|}{ Pratik Bilgi } \\
\hline Konsantrasyon & $3.82 \pm 1.01$ & $3.70 \pm 1.07$ & $3.75 \pm 1.15$ \\
\hline İmgeleme & $3.69 \pm 1.08$ & $3.61 \pm 1.09$ & $3.47 \pm 1.29$ \\
\hline Hedef Belirleme & $3.71 \pm 0.92$ & $3.69 \pm 1.08$ & $3.36 \pm 1.09$ \\
\hline Stresle Baş etme Stratejileri & $3.48 \pm 1.04$ & $3.40 \pm 1.11$ & $3.36 \pm 1.11$ \\
\hline Kendi kendine konuşma & $3.50 \pm 1.09$ & $3.35 \pm 1.19$ & $3.22 \pm 1.17$ \\
\hline Gevşeme Antrenmanı & $3.28 \pm 1.01$ & $3.09 \pm 1.10$ & $2.86 \pm 1.22$ \\
\hline \multicolumn{4}{|l|}{ Teorik Bilgi } \\
\hline İletişim & $4.10 \pm 0.77$ & $4.20 \pm 0.74$ & $3.97 \pm 0.87$ \\
\hline Yaşam Becerileri & $4.01 \pm 0.82$ & $3.98 \pm 0.79$ & $3.69 \pm 1.11$ \\
\hline Kişilik Özellikleri & $3.93 \pm 0.72$ & $3.93 \pm 0.78$ & $3.69 \pm 0.98$ \\
\hline Sakatlıktan Geri Dönüş & $3.63 \pm 0.87$ & $3.69 \pm 0.94$ & $3.64 \pm 1.04$ \\
\hline Öz farkındalık & $3.66 \pm 0.91$ & $3.64 \pm 0.87$ & $3.53 \pm 1.05$ \\
\hline Pekiştirme & $3.55 \pm 0.90$ & $3.65 \pm 0.76$ & $3.39 \pm 0.93$ \\
\hline Zihinsel Dayanıklılık & $3.50 \pm 0.93$ & $3.57 \pm 0.83$ & $3.33 \pm 1.12$ \\
\hline Genel Bilgi Puanı & $3.69 \pm 0.64$ & $3.66 \pm 0.65$ & $3.49 \pm 0.81$ \\
\hline
\end{tabular}

\section{Tutumlar}

$\begin{array}{lccr}\text { Stigma Tolerans } & 1.44 \pm 0.93 & 1.38 \pm 0.78 & 1.40 \pm 0.97 \\ \text { Zihinsel Antrenmana Güven } & 5.22 \pm 0.79 & 5.31 \pm 0.88 & 5.48 \pm 0.95 \\ \text { Kişisel Açılık } & 3.24 \pm 1.08 & 3.25 \pm 1.20 & 2.73 \pm 1.22 \\ \text { Kültü̈rel Tercih } & 4.62 \pm 1.33 & 4.78 \pm 1.22 & 4.54 \pm 1.48\end{array}$

Tablodaki değişkenler yüksek sertifika düzeyine sahip antrenörlerin ortalama puanlarına göre sıralanmıştır.

Tablo 2. Sertifika düzeyleri için parametrik olmayan görece etkiler

\begin{tabular}{lcccc}
\hline Sertifika Düzeyleri & $\begin{array}{c}\text { Stigma } \\
\text { Tolerans }\end{array}$ & Kişisel Açıklık & $\begin{array}{c}\text { SP* } \\
\text { Danışmanlığına } \\
\text { Güven }\end{array}$ & $\begin{array}{c}\text { Kültü̈rel } \\
\text { Tercih }\end{array}$ \\
\hline Düşük & .51 & .53 & .51 & .53 \\
Orta & .50 & .51 & .48 & .45 \\
Yüksek & .44 & .36 & .48 & .48 \\
\hline *SP = Spor Psikolojisi & & &
\end{tabular}

Antrenörlerin spor psikolojisine ilişkin bilgi puanları psikolojik teknikler, genel kavramlar ve toplam puan olarak değerlendirilmiştir. Bilgi puanları ile tutum puanları arasındaki ilişki Spearman korelasyon analizi ile test edilmiştir (Tablo 2). Bulgular, genel spor psikolojisi kavramlarına ilişkin bilgi puanları $(\overline{\mathrm{x}}=3.80)$ ile kişisel açıklık tutumu arasında 
etki düzeyi küçük fakat anlamlı bir ilişki olduğunu ortaya koymuştur ( $r s=.20 ; p<.001)$. Benzer şekilde, toplam bilgi puanları ile stigma tolerans ( $\mathrm{rs}=.12 ; \mathrm{p}=.04)$ ve kişisel açıklık puanları $(\mathrm{rs}=.13 ; \mathrm{p}=.01)$ arasında pozitif yönde anlamlı bir ilişki bulunmaktadır. Tablodan da görülebileceği gibi, teknik bilgi (spor psikolojisi tekniklerine ilişkin bilgi) puanları ile tutumlar arasında herhangi anlamlı bir ilişki bulunmamaktadır ( $\mathrm{p}>.05$ ). Benzer şekilde teorik bilgi puanlarıyla (spor psikolojisi kavramlarına ilişkin bilgi puanları) stigma tolerans, SP danışmanlığına güven ve kültürel tercih alt boyutları arasında anlamlı bir ilişki bulunamamıştır (p>.05). Son olarak toplam bilgi puanları ile spor psikolojisi danışmanlığına güven ve kültürel tercih arasında anlamlı bir ilişki bulunamamıştır ( $\mathrm{p}>.05)$.

Tablo 3. Antrenörlerin bilgi algıları ve tutumlar arasındaki ilişki

\begin{tabular}{ccccc}
\hline & Stigma Tolerans & Kişisel Açıklık & $\begin{array}{c}\text { SP Danışmanlığına } \\
\text { Güven }\end{array}$ & Kültürel Tercih \\
\hline Pratik Bilgi & .104 & .054 & -.087 & .047 \\
Teorik Bilgi & .096 & $.198^{* *}$ & -.065 & .082 \\
Toplam Bilgi & $.119 *$ & $.125^{*}$ & -.090 & .078 \\
\hline
\end{tabular}

Not: Tablodaki sayılar Spearman korelasyon katsayılarıdır. $* p<.05 . * * p<.01 . S P=$ Spor psikolojisi.

\section{TARTIŞMA}

$\mathrm{Bu}$ çalışmanın amacı ülkemizdeki antrenörlerin spor psikolojisi bilgi düzeylerine ilişkin algılarının belirlenmesi ve antrenörlerin bu algılarının spor psikolojisi danışmanlığına yönelik tutumları ile ilişkisinin incelenmesidir. Sonuçlar katılımcı antrenörlerin pratik ve teorik spor psikolojisi kavramlarına ilişkin bilgi düzeylerinin sınırlı (ne yüksek ne düşük) olduğunu göstermiştir. Antrenörlerin tutumlarına ilişkin bulgular ise spor psikolojisi danışmanlığına yönelik olumsuz tutumlarının (stigma tolerans) ve sporcularının spor psikolojisi danışmanlığına katılmamalarına ilişkin isteklerinin (kişisel açıklık) düşük olduğunu ortaya koyarken, spor psikolojisi danışmanlığına güvendiklerini (zihinsel antrenmanın faydasına olan inanç), ve benzer bir geçmişe sahip bir SPD ile çalışma isteğinde olduklarını (kültürel tercih) göstermiştir. Bunun yanında yüksek sertifikasyon kademesine sahip antrenörlerin orta ve düşük sertifika kademelerindeki antrenörlere spor psikolojisi danışmanlığına karşı daha olumlu tutumlara sahip oldukları görülmüştür. Son olarak antrenörlerin spor psikolojisine ilişkin bilgilerinin spor psikolojisi danışmanlığına ilişkin olumsuz tutumlarla ilişkili olduğu ortaya konmuştur.

Çalışmanın bulguları, literatür bulgularıyla paralel olarak (örn. Orlick ve Partington, 1987; Pain ve Harwood, 2004), antrenörlerin bilgi düzeylerine ilişkin algılarının yüksek olmadığını ortaya koymuştur. Antrenörlerin bu sınırlı bilgisi, spor psikolojisi becerilerinin uygulanması aşamasında önemi bir engeldir (Wrisberg ve ark., 2010). Bu noktada ülkemizdeki antrenörlerin spor psikolojisine ilişkin bilgiyi edinme yolları, edinilen bilginin kalitesi ve bu bilgiyi edinme düzeyleri önemli ölçüde belirleyicidir. Araştırmanın betimleyici istatistikleri katılımcıların spor psikolojisine ilişkin bilgiye internet, kitaplar ve antrenörlük kurslarıyla eriştiklerini ortaya koymuştur. Ancak bu kaynaklardan elde edilen bilginin içeriğine ilişkin literatürde yapılan herhangi bir çalışma bulunmamaktadır. Ülkemizde Türkçe yazılan ya da çevrilen spor psikoloji kaynakları sayısının spor bilimlerindeki diğer alanlara göre (örn. antrenman bilimi) az sayıda olduğu söylenebilir. Bununla birlikte internet yoluyla elde edilen bilginin bilimselliği her alanda olduğu gibi spor psikolojisi için de sorgulanabilir durumdadır. Bu zorluklar antrenörlerin spor psikolojisi danışmanlığına ilişkin pratik 
bilgilerinin eksikliğine yol açabilir. Örneğin Gould ve diğ. (1999) antrenörlerin zihinsel becerileri kullanımlarını araştırdıkları çalışmada 20 altyapı tenis antrenörü ile görüşmüş ve antrenörlerin spor psikolojisinin genel kavramlarına ilişkin bilgi sahibi olduklarını fakat zihinsel becerileri uygulamadıklarını ortaya koymuştur. Bu bulgular ülkemizdeki antrenörlerin aldıkları spor psikolojisi eğitimlerinin içeriğinin ve alınan eğitimin pratiğe ne kadar dönüştüğünün araştırılması gerektiğini işaret etmektedir. Son olarak, antrenörlerin spor psikolojisine ilişkin bilgi algılarına yönelik ortaya konan bu bulgular, spor psikolojisinin gelişmekte olduğu ülkelerde yaşanan eğitim problemlerinin bir uzantısı olarak değerlendirilebilir (Schinke, Papaioannou ve Schack, 2016).

Araştırmadaki bir diğer temel bulgu sertifika düzeyleri bakımından antrenörlerin spor psikolojisi danışmanlığına ilişkin tutumları arasında bulunan farklılıktır. Bu farklılığın kişisel açıklık boyutundan kaynaklandığı görülmüş ve sonuçlar yüksek sertifika düzeyindeki antrenörlerin diğer kademe düzeylerindeki antrenörlere göre daha düşük kişisel açıklık puanı aldığını ortaya koymuştur. Kişisel açıklık alt boyutu antrenörlerin, sporcularının spor psikolojisi danışmanından destek almalarındaki isteksizliğini ifade etmektedir (Zakrajsek ve Zizzi, 2008). Benzer bulgular Zakrajsek, Martin ve Zizzi (2011) tarafından Amerikan lise futbol antrenörlerinde yapılan çalışmada da bulunmuştur. Çalışmada 6 sene altında deneyimi olan ve yaşı 30 altında olan antrenörlerin daha deneyimli antrenörlere göre spor psikolojisi danışmanlığına karşın daha olumsuz tutumlar sergilediğini ortaya koymuştur. Araştırmacılar deneyimsiz antrenörlerin spor psikolojisi danışmanlığına ilişkin bu olumsuz yaklaşımlarında birçok faktörün etkili olabileceğini ancak deneyimli antrenörlerin daha uzun süreler spor psikolojisi bilgisi almalarının etkili olabileceğini belirtmişlerdir. Martin (2005) tarafından sporcularla yapılan çalışmada da kolej düzeyindeki sporcuların lise düzeyindeki sporculara göre spor psikolojisi danışmanlığına yönelik daha olumlu tutumlara sahip olduğu bulunmuştur. Antrenör ve sporcular açısından ortaya konan bu bulgular çalışmamızdaki bulgularla paraleldir. Bu çalışmada odaklanılan sertifika düzeyi, antrenörlerin deneyimlerini ve çalışma seviyelerini ifade eden bir özellik olarak değerlendirilebilir. Yüksek sertifika düzeyindeki katılımcı antrenörler sertifika gereksinimlerinden dolayı, diğer sertifika düzeyindeki antrenörlere göre daha deneyimlidir. Bu antrenörlük deneyimleriyle birlikte üst kademelerde görev almaları antrenörlerin spor psikolojisinin önemini kavramaları ve alana ilişkin teknik, bilgi ve becerileri sporcularına aktarma eğiliminde olmalarını sağlamış olabilir. Öte yandan bir başka neden ise Zakreajsek, Martin ve Zizzi'nin (2011) ifade ettiği gibi alt sertifika düzeyindeki antrenörler kariyerlerinin başında daha çok teknik ve taktik bilgilere odaklanmış ve sporun zihinsel yönünün önemini henüz kavramamış olabilirler.

Çalı̧̧madaki bir diğer bulgu antrenörlerin bilgi düzeyi algıları ile spor psikolojisi danışmanlı̆̆ına tutumları arasındaki ilişkilerdir. Araştırma sonuçlarına göre antrenörlerin pratik bilgi düzeyleri ile tutumları arasında anlamlı bir ilişki gözlemlenmezken teorik bilgi düzeyleri ile kişisel açılık alt boyutunda anlamlı pozitif yönlü bir ilişki olduğu görülmüş̧ür. Antrenörlerin sporcularının spor psikolojisi danışmanlığını almalarına ilişkin olumsuz tutumlarını ifade eden bu alt boyutla teorik bilgiler arasındaki bu pozitif yönlü ilişki ilginç bir bulgudur. Her ne kadar korelasyon analizi nedenselliği yorumlamamıza izin vermese de bu bulgu ilgili literatürde yapılan diğer çalışmalardaki bulgularla çelişmektedir (örn. Wrisberg ve diğ., 2010). Antrenörlerin bilgi düzeylerinin artı̧̧ıla olumsuz tutumların artış1 makalenin önceki bölümlerinde ifade edilen bilgi içeriklerinin sorgulanması durumunun önemini ortaya koymaktadır. Bununla birlikte sadece bilginin antrenörlerde danışmanlığa ilişkin olumlu tutumlar oluşturma konusunda yetersiz kalabileceği diğer çalışmalarca da ifade edilmiştir (Zakrajsek, 2007). Antrenörler spor psikolojisine ilişkin bazı temel bilgileri alırken danışmanlığın sağladığı yararlar konusunda bilgisiz olabilirler (Rice, 1996) ve bu durum onların tutumlarında olumlu değişimlere yol açmayabilir. 
Bu çalışma Türk antrenörlerin spor psikolojisi bilgileri ve spor psikolojisi danışmanlığına ilişkin tutumları hakkında önemli ipuçları sağlamış olsa da çeşitli sınırlılıklara sahiptir. Antrenörlerin bilgi düzeyleri öznel bir yöntem olan anket yoluyla ölçülmüştür. Bu durum antrenörlerin spor psikolojisine ilişkin bilgilerinin düzeyine yönelik algıları hakkında okuyucuya fikir vermekle birlikte nesnel bir bilgi ölçümü sağlamamaktadır. Gelecekteki çalışmalar antrenörlerin spor psikolojine ilişkin bilgilerini nesnel olarak ölçebilirler. Bir diğer sınırlılık ise çalışmaya çok az kadın antrenörün katılmasıdır. Bu durum kadınlar ve erkekler arasında bilgi ve danışmanlık tutumları arasındaki olası farkları saptamaya olanak sağlamamıştır. Benzer şekilde bu çalışmada antrenörlerin yaşları, eğitim düzeyleri, çalıştıkları branşlar ve hatta çalışma yerleri gibi diğer özelliklerinin spor psikolojisi danışmanlığına ilişkin tutumları ve bilgi düzeylerini hangi ölçüde etkilediği gibi sorular sonuçların yorumlanabilirliğini zorlaştırmamak adına çalışmanın kapsamına alınmamıştır. İleride yapılacak çalışmalar bu tür antrenör özelliklerinin ilgili değişkenler üzerine etkilerine odaklanabilirler. Ayrıca bu çalışmada yapılan korelasyon analizinin yanında antrenörlere özgü değişkenlerin de dahil edildiği kapsamlı modeller geliştirilerek (örn. regresyon modelleri) ayrıntılı analizler gerçekleştirilebilir. Son olarak kültürel farklılıklar çalışma bulgularımızın genellenebilirliğini sınırlayabilir. Hizmet yönelimleri, destek arama davranışı ve uygulamalı hizmetlerdeki farklılıklar kültürel spor psikolojisi alanında çalışılmaktadır (Örneğin, Naoi, Watson, Deaner, \& Sato, 2011; Schinke \& Hanrahan, 2009). Dolayısıyla çalışmadaki bulgular kültürel farklılıklar göz önüne alınarak değerlendirilmeli ve gelecekte bu tür çalışmaların ülkemizde arttırılması sağlanmalıdır.

\section{SONUÇ VE ÖNERÍLER}

Sonuç olarak çalışmanın bulguları Türk antrenörlerin spor psikolojisine ilişkin bilgi düzeylerini sınırlı olarak algıladıklarını ve spor psikolojisi danışmanlığına ilişkin genel anlamda olumlu tutumlar geliştirdiklerini ortaya koymuştur. Yüksek sertifika kademesine sahip antrenörlerin daha düşük sertifikasyon kademesine sahip antrenörlere göre sporcularının spor psikolojisi danışmanlığına katılımlarında daha olumlu tutumlar geliştirdikleri görülmüştür.

İleride yapılacak araştırmalarda antrenörlerin bilgi ve spor psikolojisi danışmanlığına yönelik tutumlarını etkileyen branş, yaş vb. değişkenlerin etkilerinin incelenmesi hem uygulama hem de akademik anlamda spor psikolojisi alanı açısından önemli bilgiler sunacaktır. Bu bağlamda SPD'lerle çalışan antrenörlerin yaşadığı deneyimlerin nitel araştırmalar kapsamında derinlemesine incelenmesi Türk antrenörlerin danışman tercihleri, uygulamaya ilişkin algıları ve SPD’lerde aradıkları özellikler hakkında önemli bilgiler sağlayabilir. Benzer şekilde, antrenörlerin spor psikolojisi bilgilerinin sınırlılığı göz önüne alındığında aldıkları eğitimlerin içerikleri ve bu bilgilerin pratiğe nasıl dönüştüğü de antrenörlere verilen spor psikolojisi eğitimlerin geliştirilmesini sağlayarak alana katkıda bulunabilir. Genel anlamda spor alanının paydaşları olan antrenörler, uygulayıcılar, yöneticiler ve ailelere odaklanan, onların görüşlerini temel alan daha fazla araştırma yapılmasına ihtiyaç bulunmaktadır.

Uygulama açısında bakıldığında spor psikolojisi eğitimlerinin, SPD’lerin danışmanlığı nasıl gerçekleştirdiğini, etkili danışmanlık süreçlerini nasıl sağladıklarını ve antrenörlerin bu süreçlerdeki rol ve sorumluluklarını kapsayan bilgileri içermesi gerekliliğinin olumsuz tutumların (damgalama vb.) ortadan kaldırılması adına önemli olduğu düşünülmektedir. $\mathrm{Bu}$ kapsamda eğitim faaliyetlerinin yeniden gözden geçirilerek bu bilgileri içermesi sağlanabilir. Ayrıca danışmanlığa özgü seminerlerle antrenörlerin spor psikolojisi danışmanlığını daha iyi kavramaları sağlanabilir. Sonuç olarak antrenörlerin teorik bilgiler yanında spor psikolojisi danışmanlığına ilişkin bilgiler alması SPD’lerin daha etkili çalışmasını sağlayarak alanın gelişmesine önemli katkılar sağlayacaktır. 


\section{KAYNAKLAR}

1. Anderson AG, Hodge KP, Lavallee D, Martin SB. (2004). New Zealand athletes' attitudes towards seeking sport psychology consultation. The New Zealand Journal of Psychology, 33(3), 129-136.

2. Anderson R, Hanrahan SJ, Mallett CJ. (2014). Investigating the optimal psychological state for peak performance in Australian elite athletes. Journal of Applied Sport Psychology, 26(3), 318-333.

3. Arnold R, Sarkar M. (2015). Preparing athletes and teams for the Olympic Games: Experiences and lessons learned from the world's best sport psychologists. International Journal of Sport and Exercise Psychology, 13(1), 4-20.

4. Brunner E, Domhof S, Langer F (2002). Nonparametric Analysis of Longitudinal Data in Factorial Experiments. John Wiley and Sons: New York, NY.

5. Connole IJ, Watson JC, Shannon VR, Wrisberg C, Etzel E, Schimmel C. (2014). NCAA athletic administrators' preferred characteristics for sport psychology positions: a consumer market analysis. The Sport Psychologist, 28(4), 406-417.

6. Dieffenbach K, Gould D, Moffett A. (2002). The coach's role in developing champions. International Journal of Volleyball Research, $5(1), 30-32$.

7. Ellis AR, Burchett WW, Harrar SW, Bathke AC (2017). Nonparametric inference for multivariate data: the R package npmv. Journal of Statistical Software, 76(4), 1-18.

8. Gee CJ. (2010). How does sport psychology actually improve athletic performance? A framework to facilitate athletes' and coaches' understanding. Behavior modification, 34(5), 386-402.

9. Gould D, Damarjian N, Medbery R. (1999). An examination of mental skills training in junior tennis coaches. The Sport Psychologist, 13(2), 127-143.

10. Gould D, Tammen V, Murphy S, \& May J (1991). An evaluation of US Olympic sport psychology consultant effectiveness. The Sport Psychologist, 5(2), 111-127.

11. Görgülü R (2018). Spor ve egzersiz psikolojisinde kariyer basamakları, güçlükler ve tehlikeler: Birleşik Krallık’tan model uygulamalar. Spor Bilimleri Araştırmaları Dergisi, 3(1), 164-178.

12. Gucciardi DF, Gordon S, Dimmock JA. (2009). Evaluation of a mental toughness training program for youth-aged Australian footballers: I. A quantitative analysis. Journal of Applied Sport Psychology, 21(3), 307-323.

13. Krosnick JR, Petty RE. (1995). Attitude strenght: An overview. (RE Petty, JR Krosnick, Ed.). Attitude strength: Antecedents and consequence. s.1-24. Hillsdale, NJ: Lawrence Erlbaum Associates, Inc.

14. Lubker JR, Visek AJ, Geer JR, Watson II JC (2008). Characteristics of an effective sport psychology consultant: Perspectives from athletes and consultants. Journal of Sport Behavior, 31(2), 147.

15. Mallett CJ, Hanrahan SJ. (2004). Elite athletes: why does the 'fire'burn so brightly? Psychology of Sport and Exercise, 5(2), 183-200.

16. Martin SB. (2005). High school and college athletes' attitudes toward sport psychology consulting. Journal of Applied Sport Psychology, 17(2), 127-139.

17. Martin SB, Akers A, Jackson AW, Wrisberg CA, Nelson L, Leslie PJ, ve diğ. (2001). Male and female athletes' and nonathletes' expectations about sport psychology consulting. Journal of Applied Sport Psychology, 13(1), 18-39.

18. Martin SB, Kellmann M, Lavallee D, Page SJ. (2002). Development and psychometric evaluation of the sport psychology attitudesrevised form: A multiple group investigation. The Sport Psychologist, 16(3), 272-290.

19. Martin SB, Zakrajsek RA, Wrisberg CA. (2012). Attitudes toward sport psychology and seeking assistance: Key factors and a proposed model. Psychology of attitudes, 1-33.

20. Naoi A, Watson J, Deaner H, Sato M. (2011). Multicultural issues in sport psychology and consultation. International Journal of Sport and Exercise Psychology, 9(2), 110-125. doi:10.1080/1612197X.2011.567101

21. Orlick T, Partington J. (1987). The sport psychology consultant: Analysis of critical components as viewed by Canadian Olympic athletes. The Sport Psychologist, 1(1), 4-17.

22. Pain MA, Harwood CG. (2004). Knowledge and perceptions of sport psychology within English soccer. Journal of sports sciences, 22(9), 813-826.

23. Partington J, Orlick T. (1987). The sport psychology consultant: Olympic coaches' views. The Sport Psychologist, 1(2), 95-102.

24. Reid C, Stewart E, Thorne G. (2004). Multidisciplinary sport science teams in elite sport: Comprehensive servicing or conflict and confusion? The Sport Psychologist, 18(2), 204-217.

25. Reverter-Masía J, Legaz-Arrese A, Munguía-Izquierdo D, Roig-Pull M, Gimeno-Marco F, Barbany JR. (2008). The use of sports psychology consultants in elite sports teams. Revista de psicologia del deporte, 17(1). 
26. Rice TS (1996). Should coaches administer psychological interventions to their athletes?. Yayınlanmamış doktora tezi. West Virgina University, Morgantown.

27. Schinke R, Hanrahan SJ. (2009). Cultural sport psychology. Champaign, IL: Human Kinetics.

28. Schinke RJ, Papaioannou AG, Schack T. (2016). Sport Psychology in emerging countries. International Journal of Sport and Exercise Psychology, 14(2), 103-185

29. Schinke RJ, Si G, Zhang L, Elbe AM, Watson J, Harwood,C, Terry PC (2018). Joint position stand of the ISSP, FEPSAC, ASPASP, and AASP on professional accreditation. Psychology of Sport and Exercise, 38, 107-115.

30. Sullivan J, Hodge KP. (1991). A survey of coaches and athletes about sport psychology in New Zealand. The Sport Psychologist, 5(2), 140-151.

31. Thelwell RC, Wood J, Harwood C, Woolway T, Van Raalte JL (2018). The role, benefits and selection of sport psychology consultants: Perceptions of youth-sport coaches and parents. Psychology of Sport and Exercise, 35, 131-142.

32. Türkiye Basketbol Federasyonu, 2014. Türkiye Basketbol Federasyonu Ana Statüsü. 29136 sayılı Resmi Gazete.

33. Wilson KA, Gilbert JN, Gilbert WD, Sailor SR (2009). College athletic directors' perceptions of sport psychology consulting. The Sport Psychologist, 23(3), 405-424.

34. Wrisberg CA, Withycombe JL, Simpson D, Loberg LA, Reed A. (2012). NCAA Division-I administrators' perceptions of the benefits of sport psychology services and possible roles for a consultant. The Sport Psychologist, 26(1), 16-28.

35. Wrisberg, CA, Loberg LA, Simpson D, Withycombe JL, Reed A. (2010). An exploratory investigation of NCAA Division-I coaches' support of sport psychology consultants and willingness to seek mental training services. The Sport Psychologist, 24(4), 489-503.

36. Zakrajsek RA, Martin SB, Zizzi SJ. (2011). American high school football coaches' attitudes toward sport psychology consultation and intentions to use sport psychology services. International Journal of Sports Science \& Coaching, 6(3), 461-478.

37. Zakrajsek RA., Steinfeldt JA, Bodey KJ, Martin SB, Zizzi SJ. (2013). NCAA Division I coaches' perceptions and preferred use of sport psychology services: A qualitative perspective. The Sport Psychologist, 27(3), 258-268.

38. Zakrajsek RA, Zizzi SJ. (2007). Factors influencing track and swimming coaches' intentions to use sport psychology services. Athletic Insight: The Online Journal of Sport Psychology, 9(2), 1-21.

39. Zakrajsek RA, Zizzi SJ. (2008). How do Coaches' Attitudes Change When Exposed to a Sport Psychology Workshop? Journal of Coaching Education, 1(1), 66-83. 